\title{
Simultaneous production of isopropanol, butanol, ethanol and 2,3-butanediol by Clostridium acetobutylicum ATCC 824 engineered strains
}

\author{
Florent Collas ${ }^{1,2}$, Wouter Kuit ${ }^{1,3}$, Benjamin Clément ${ }^{2}$, Rémy Marchal ${ }^{2}$, Ana M López-Contreras ${ }^{1 *}$
} and Frederic Monot ${ }^{2}$

\begin{abstract}
Isopropanol represents a widely-used commercial alcohol which is currently produced from petroleum. In nature, isopropanol is excreted by some strains of Clostridium beijerinckii, simultaneously with butanol and ethanol during the isopropanol butanol ethanol (IBE) fermentation. In order to increase isopropanol production, the gene encoding the secondary-alcohol dehydrogenase enzyme from C. beijerinckii NRRL B593 (adh) which catalyzes the reduction of acetone to isopropanol, was cloned into the acetone, butanol and ethanol (ABE)-producing strain C. acetobutylicum ATCC 824. The transformants showed high capacity for conversion of acetone into isopropanol (> 95\%). To increase isopropanol production levels in ATCC 824, polycistronic transcription units containing, in addition to the adh gene, homologous genes of the acetoacetate decarboxylase (adc), and/or the acetoacetyl-CoA:acetate/butyrate:CoA transferase subunits $A$ and $B$ ( $C t f A$ and $c t f B$ ) were constructed and introduced into the wild-type strain. Combined overexpression of the $C t f A$ and $C t f B$ genes resulted in enhanced solvent production. In non-pH-controlled batch cultures, the total solvents excreted by the transformant overexpressing the adh, ctfA, ctfB and adc genes were $24.4 \mathrm{~g} / \mathrm{L} \mathrm{IBE}$ (including $8.8 \mathrm{~g} / \mathrm{L}$ isopropanol), while the control strain harbouring an empty plasmid produced only $20.2 \mathrm{~g} / \mathrm{L} \mathrm{ABE}$ (including $7.6 \mathrm{~g} / \mathrm{L}$ acetone). The overexpression of the adc gene had limited effect on IBE production. Interestingly, all transformants with the adh gene converted acetoin (a minor fermentation product) into 2,3-butanediol, highlighting the wide metabolic versatility of solvent-producing Clostridia.
\end{abstract}

Keywords: Clostridium, Butanol, Biobutanol, Isopropanol, IBE fermentation, 2,3-butanediol, Acyl-CoA transferase

\section{Introduction}

The limited supply and the negative environmental effects of the use of petroleum-derived fuels and chemicals have stimulated efforts for the development of more environmentally-friendly processes. In this respect, the fermentation of carbohydrates into acetone, butanol and ethanol (ABE) or isopropanol, butanol and ethanol (IBE) is a promising way for the production of green chemicals and fuels. In the past, both ABE and IBE fermentations were performed worldwide at industrial scale until they were replaced by petrochemical processes (Jones and Woods 1986; Rogers et al. 2006). Many resources are currently being devoted to develop economically-viable

\footnotetext{
*Correspondence: ana.Lopez-Contreras@wur.nl

${ }^{1}$ Food and Biobased Research, Wageningen University and Research Centre, Bornse Weilanden 9, 6708, WG Wageningen, Netherlands

Full list of author information is available at the end of the article
}

fermentation processes based primarly on lignocellulosic biomass hydrolysates as substrates (Dürre 2007, 2008; López-Contreras et al. 2010; Green 2011).

For fuel applications, the IBE mixture appears to be more attractive than the $\mathrm{ABE}$ one. Isopropanol shows a higher energy density than acetone (23.9 MJ/L vs $22.6 \mathrm{MJ} / \mathrm{L})$ and this mixture has already been used as an additive for gasoline or diesel oil (Peralta-Yahya and Keasling 2010). Isopropanol can be catalytically condensed into di-isopropyl ether (DIPE) (Logsdon and Loke 2000). DIPE displays good fuel properties and could substitute methyl tert-butyl ether (MTBE) as isooctane index enhancer in gasoline composition (Huang and Sorensen 1990). Another important potential application of biologicallyproduced isopropanol is as a precursor for green propylene, which is the second most important chemical intermediate in the petrochemical industry after ethylene. 
Propylene is used in many chemical reactions for the synthesis of a wide variety of products, including plastic materials.

The clostridial species that produce neutral solvents (ABE or IBE) are strictly anaerobes, rod-shaped and spore-forming bacteria. Most of them, such as C. acetobutylicum ATCC 824, produce ABE but some others, such as C. beijerinckii NRRL B593, excrete IBE (George et al. 1983; Chen and Hiu 1986). ABE and IBE batch fermentations are similar, displaying a biphasic kinetic pattern (Jones and Woods 1986; Girbal and Soucaille 1998). After production of acetic and butyric acids in exponential growth, fermentation switches to formation of neutral solvents shortly before entering stationary phase. In the IBE fermentation, depending on the strain and the cultivation conditions, residual acetone may also be an end-product (Ismaiel et al. 1993).

In C. beijerinckii NRRL B593, the reduction of acetone into isopropanol is catalyzed by a NADPH-dependent secondary-alcohol dehydrogenase (s-Adh), which has been extensively characterized (Yan et al. 1988; Ismaiel et al. 1993; Korkhin et al. 1998; Goihberg et al. 2010). Although the s-Adh was clearly distinct from clostridial primary-alcohol dehydrogenases (Chen 1995) that reduce butyraldehyde into butanol, the s-Adh showed activity on both primary and secondary alcohols, with a preference for secondary ones (Ismaiel et al. 1993). Kinetic studies confirmed that the physiological substrate was acetone.

Metabolic engineering has been used to create pathways for isopropanol production in Escherichia coli. Introduction of four genes from $C$. acetobutylicum (ctfA, ctfB, adc and thiolase $(t h l)$ ) into $E$. coli generated a strain capable of producing acetone (Bermejo et al. 1998). By introduction of the $C$. beijerinckii adh gene in combination with the aforementioned genes, isopropanol excretion by $E$. coli was achieved up to the concentrations of $4.9 \mathrm{~g} / \mathrm{L}$ (Hanai et al. 2007) and $13 \mathrm{~g} / \mathrm{L}$ (Jojima et al. 2008). The engineered $E$. coli strains surpassed the best reported wild-type clostridial strains, $C$. beijerinckii and $C$. isopropylicum, excreting approximately $4 \mathrm{~g} / \mathrm{L}$ isopropanol (Groot and Luyben 1986; Matsumura et al. 1992). A major advantage of the engineered $E$. coli strains was the lack of important competing pathways for by-products. Recently, the adh gene from $C$. beijerinckii was cloned into the ABE-producing strain $C$. acetobutylicum ATCC 824. The resulting transformants excreted $6.1 \mathrm{~g} / \mathrm{L}$ isopropanol and a minor amount of acetone (Lee et al. 2012).

In the present study, different IBE-producing transformants of $C$. acetobutylicum that showed high isopropanol excretion capacities have been constructed. The fermentation performances of the transformants were characterized in batch cultures using laboratoryscale bioreactors with or without $\mathrm{pH}$-control and compared to those of the wild-type IBE or ABEproducing strains. In addition, formation of 2,3-butanediol by $C$. acetobutylicum transformant strains harbouring the $a d h$ gene was described and characterized for the first time.

\section{Materials and methods}

\section{Strains and cultivation conditions}

The microorganisms used are listed in Table 1. E. coli culture stocks were stored at $-80^{\circ} \mathrm{C}$ in $20 \%(\mathrm{v} / \mathrm{v})$ glycerol. E. coli strains were cultivated at $37^{\circ} \mathrm{C}$ with agitation (250 rpm) in LB (lysogeny broth) medium (Bertani 2004). For cultivation of E. coli BW25113 harbouring pMTL500E based plasmids, the LB medium was supplemented with $2 \%(\mathrm{w} / \mathrm{w})$ glucose.

Clostridial wild-type and transformants were stored as spore suspensions at $-20^{\circ} \mathrm{C}$ in $15 \%(v / v)$ glycerol. Prior to the inoculation of pre-cultures, each spore suspension $(500 \mu \mathrm{L})$ was heat-shocked in a water bath for $10 \mathrm{~min}$ at $70^{\circ} \mathrm{C}$ (C. acetobutylicum ATCC 824 and its transformants) or $1 \mathrm{~min}$ at $100^{\circ} \mathrm{C}$ (C. beijerinckii NRRL B593). Culture media for Clostridia were made anaerobic by sparging with nitrogen gas. Cultures and pre-cultures were performed in CM1 medium (Kuit et al. 2012) which contains, per liter: yeast extract, $5.0 \mathrm{~g} ; \mathrm{KH}_{2} \mathrm{PO}_{4}$, 1.0 g; $\mathrm{K}_{2} \mathrm{HPO}_{4}, 0.76 \mathrm{~g}$; ammonium acetate, $3.0 \mathrm{~g}$; p-aminobenzoic acid, $0.10 \mathrm{~g} ; \mathrm{MgSO}_{4} .7 \mathrm{H}_{2} \mathrm{O}, 1.0 \mathrm{~g}$; and $\mathrm{FeSO}_{4} .7 \mathrm{H}_{2} \mathrm{O}, 0.5 \mathrm{~g}$, glucose, 90 g. Pre-cultures of

Table 1 Strains and plasmids used in this study

\begin{tabular}{|c|c|c|}
\hline Strain or plasmid & Relevant properties & References \\
\hline E. coli XL1 blue & $\begin{array}{l}\text { Cloning and } \\
\text { plasmid maintenance }\end{array}$ & \\
\hline $\begin{array}{l}\text { E. coli DH10B } \\
\text { (pAN2) }\end{array}$ & Plasmid methylation & \\
\hline $\begin{array}{l}\text { E. coli BW } \\
25113\end{array}$ & Ipa operons expression & \\
\hline $\begin{array}{l}\text { C. beijerinckii } \\
\text { NRRL B593 }\end{array}$ & $\begin{array}{l}\text { Wild type, } \\
\text { Isopropanol natural producer }\end{array}$ & $\begin{array}{l}\text { (George et al. 1983, } \\
\text { Chen et al. 1986) }\end{array}$ \\
\hline $\begin{array}{l}\text { C. acetobutylicum } \\
\text { ATCC824 }\end{array}$ & & $\begin{array}{c}\text { (Jones and Woods } \\
\text { 1986) }\end{array}$ \\
\hline pMTL500E & Empty vector (erm $\left.B^{R} / a m p^{R}\right)$ & (Oultram et al. 1988) \\
\hline -pFC002 & thlp_[adh] & this article \\
\hline -pFC005 & thlp_[adh; adc] & this article \\
\hline -pFC006 & thlp_[adh; ctfA; ctfB] & this article \\
\hline -pFC007 & thlp_[adh; adc; ctfA; ctfB] & this article \\
\hline PTHL & thlp_[thl], $\mathrm{kan}^{R}$ & this article \\
\hline pAN2 & $t t c^{R}$ & $\begin{array}{l}\text { (Mermelstein and } \\
\text { Papoutsakis1993, } \\
\text { Heap et al. 2007) }\end{array}$ \\
\hline
\end{tabular}

Clostridium/E. coli selective marker are indicated in parentheses. 
C. beijerinckii were grown in medium containing $60 \mathrm{~g} / \mathrm{L}$ glucose.

Batch fermentations were carried out anaerobically in 2-L (1-L working volume) Applikon glass bioreactors (Applikon, The Netherlands) using CM1 medium. When needed, $\mathrm{pH}$ was maintained at 5.0 by automatic addition of $4 \mathrm{M} \mathrm{KOH}$ solution. Static flask fermentations were carried out anaerobically in $120 \mathrm{~mL}$ serum bottles with $50 \mathrm{~mL}$ of CM1 medium.

For the preparation of clostridial competent cells, cells were grown on CG medium (Roos et al. 1985), as described previously (Oultram et al. 1988). When required, culture media were supplemented with ampicillin $(100 \mu \mathrm{g} / \mathrm{mL})$, chloramphenicol $(30 \mu \mathrm{g} / \mathrm{mL})$, erythromycin $(50 \mu \mathrm{g} / \mathrm{mL}$ or $30 \mu \mathrm{g} / \mathrm{mL}$ for liquid cultures and plates, respectively).

Microbial growth was monitored by optical density measurements at $600 \mathrm{~nm}$ (Pharmacia Biotech Ultrospec 2000).

\section{Plasmid construction and transformation}

Genomic DNA from Clostridium strains was isolated using GenElute bacterial genomic DNA kit from SigmaAldrich. Plasmid DNA from E. coli strains was extracted using the GeneJet plasmid miniprep kit from Fermentas. PCR amplifications were done using high fidelity PCR master mix (Roche). DNA restrictions and ligations were performed using New England Biolabs restriction enzymes (ApaI, Fnu4H1, SpeI, SphI, XbaI and XhoI) and T4 DNA-Ligase enzyme, respectively. The oligonucleotides used are listed in Table 2 and were synthesized by Eurogenetec. Chemically competent E. coli strains were prepared using the Z-competent kit from Zymo-research. Kits were used according to supplier protocols.

The constructs used for the $C$. acetobutylicum transformation were based on the E. coli/Clostridium shuttle

Table 2 Oligonucleotides used for the plasmid constructions

\begin{tabular}{|c|c|}
\hline Primers & Sequence $\left(5^{\prime}-3^{\prime}\right)$ \\
\hline thlp-for & GCATGCGAATTTAGAATGAAGTTCTTATGCA \\
\hline thlp_rev & AAAAGGGCCCCCATAGTTATCCCTAATTTATACG \\
\hline thl g_rev & СTCTGTAGAACTAGTTAATAATTCTACAGAGTTATTITAAAC \\
\hline s-adh-for & TTTTGGGCCCTTAGACTATTAAAGGAATATTITIAAGG \\
\hline s-adh-rev & TTTTCTCGAGGTATAATCCTCCATGATCTATTATG \\
\hline ctfAB for & $\begin{array}{l}\text { CAACTACTCGAGATAATTTTCTAGAGAATTTAAAAGGAGG } \\
\text { GATTAAAATG }\end{array}$ \\
\hline ctfAB rev & $\begin{array}{l}\text { AATGGTACTAGTTATTITTGTCGACTGTTTCATAGTATTTC } \\
\text { ITTCTAAACAGCC }\end{array}$ \\
\hline adc for & $\begin{array}{l}\text { AAACAACTCGAGTTATAATCTAGATATAAATAAATAGGA } \\
\text { CTAGAGGCG }\end{array}$ \\
\hline adc rev & $\begin{array}{l}\text { AAAAATACTAGTTACCATTTAAGTCGACTCTTATTTITATTA } \\
\text { CTTAAG }\end{array}$ \\
\hline
\end{tabular}

Bases not complementary with genomic DNA are in italics; Added restriction sites (Apal, Sall, spel, Sphl, Xbal and Xhol,) are underlined Ribosome binding sites are in bold. vector pMTL500E (Table 1). The thiolase promoter was PCR-amplified from genomic-DNA of C. acetobutylicum ATCC 824 using thlp_for and thlp_rev oligonucleotides and digested by ApaI and SphI. The adh gene was PCRamplified from $C$. beijerinckii NRRL B593 genomic-DNA using $a d h \_$for and $a d h \_r e v$ oligonucleotides and digested by $A p a \mathrm{I}$ and $X h o \mathrm{I}$. The thl promoter and $a d h$ gene sequences were simultaneously cloned into pMTL500E plasmid (digested by SphI and XhoI) to yield pFC002 construct. Genes from C. acetobutylicum ATCC 824 were amplified by PCR on genomic DNA using $a d c$ for and $a d c \_r e v$ oligonucleotides for $a d c, c t f A B \_f o r$ and $c t f A B \_r e v$ oligonucleotides for $c t f A$ and $c t f B$. PCR amplifications of adc gene and $c t f A \_c t f B$ genes were digested by $X h o I$ and SpeI restriction enzymes and cloned into pFC002 digested $X h o I$ and $X b a I$ to yield pFC005 and pFC006, respectively. PCR amplification of $a d c$ gene was subsequently cloned into pFC006 digested XhoI and XbaI to yield pFC007.

Plasmid DNA constructs were introduced into chemically competent $E$. coli DH10B harbouring pAN2 (Heap et al. 2007) for methylation prior to transformation into C. acetobutylicum as described earlier (Mermelstein and Papoutsakis 1993). Correct methylation was checked by restriction analysis with Fnu4HI. Methylated pFC002, pFC005, pFC006, pFC007 and methylated pMTL500E plasmids (Table 1) were electroporated into C. acetobutylicum ATCC 824 as described by Oultram et al (Oultram et al. 1988). Erythromycin-resistant colonies were cultivated in CGM liquid medium and total DNA was extracted as described above. The presence of the respective construct in the transformants obtained was confirmed by PCR on DNA extracted from the different colonies using specific oligonucleotides for the specific inserts. Transformant strains harbouring the right construct were found for all constructs (results not shown). Transformant strains were stored as spore suspensions and kept at $-20^{\circ} \mathrm{C}$.

The thiolase transcription unit was amplified from C. acetobutylicum genomic DNA using oligonucleotides thlp_for and thlp_rev (Table 2). The amplificate was cloned into pCR blunt II Topo (Invitrogen) to yield pTHL. The plasmid pTHL was cotransformed with pFC002, pFC005, pFC006, pFC007 or pMTL500E in chimiocompetent E. coli BW25113.

\section{Reduction of ketones by cell-free extracts}

For preparation of cell-free extracts (CFEs) for enzymatic assays, C. acetobutylicum transformants and C. beijerinckii wild type strains were grown anaerobically in $100 \mathrm{~mL}$ of CM1 medium with $60 \mathrm{~g} / \mathrm{L}$ glucose. After $15-20 \mathrm{~h}$ of culture, cells were harvested at $4^{\circ} \mathrm{C}$ by centrifugation at $15,000 \mathrm{~g}$ for $7 \mathrm{~min}\left(\mathrm{OD}_{600}: 1.5-2.0\right)$. Pellets were suspended in $20 \mathrm{~mL}$ of $50 \mathrm{mM}$ sodium-HEPES buffer $(\mathrm{pH} 8.5)$ containing DTT $(0.2 \mathrm{mM})$ and a set of 
protease inhibitors (Complete; Mini, Roche, 1 tablet in $50 \mathrm{~mL}$ ) and washed twice. Pellets were then suspended in $3 \mathrm{~mL}$ of $50 \mathrm{mM}$ sodium-HEPES buffer. Cell suspensions were frozen in liquid nitrogen and stored overnight at $-80^{\circ} \mathrm{C}$ in anaerobic conditions. Cell suspensions were then slowly thawed, loaded in a French Press (Thermo Electron Corporation) and homogenized by two passes at 16,000 psi. When used, CFEs were kept on ice. Protein content in the CFEs was determined by the Bradford method (Biorad) with BSA as standard.

Reduction of acetone or racemic acetoin (D/L 3-hydroxy-2-butanone, Fluka) by s-Adh was carried out at $37^{\circ} \mathrm{C}$ in $50 \mathrm{mM}$ of Tris buffer ( $\left.\mathrm{pH} 7.5\right)$ with $0.2 \mathrm{mM}$ of NADPH and $50 \mathrm{mM}$ of substrate. NADPH decrease was monitored by absorbance decrease at $340 \mathrm{~nm}$ using a Safire spectrophotometer (Tecan).

\section{Analytical procedures}

Samples taken during fermentation were centrifuged at $20,000 \mathrm{~g}$ for $5 \mathrm{~min}$ and supernatants were stored at $-20^{\circ} \mathrm{C}$. Metabolite concentrations (sugars, organic acids, solvents and 2,3-butanediol) were determined by HPLC as previously described (Gosselink et al. 1995; Siemerink et al. 2011). A solution of 4-methyl valeric acid (SigmaAldrich) at $30 \mathrm{mM}$ was used as an internal standard.

\section{Results}

\section{Construction of expression vectors}

The well-studied ABE-producing strain C. acetobutylicum ATCC 824 was engineered to be an IBE producer. For this purpose, the coding sequence of the $a d h$ gene from $C$. beijerinckii NRRL B593 was cloned downstream of the promoter sequence of the thiolase gene $(t h l)$ from $C$. acetobutylicum ATCC 824 to form pFC002 plasmid (Table 1). The promoter sequence of the thiolase gene was chosen in order to maximize expression of the $a d h$ gene, since the thiolase gene of C. acetobutylicum was reported to be constitutively expressed (Hartmanis and Gatenbeck 1984; Tummala et al. 1999; Alsaker and Papoutsakis 2005). To upregulate the acetone pathway in the host organism, genes encoding the enzymes active in acetoacetylCoA to acetone conversion i.e. acetoacetate decarboxylase $(a d c)$ and acetoacetyl-CoA : acetate/butyrate: CoA transferase subunits $\mathrm{A}$ and $\mathrm{B}$ (ctfA and $c t f B$ ) were cloned into pFC002, downstream of the $a d h$ gene, resulting in the construct pFC007 (Table 1). Genes $a d c, c t f A$ and $c t f B$ were expressed under the control of the thl-promoter. The role of each gene over expressed in pFC007 was subsequently assessed by constructing different combinations of $a d h$, adc, ctfA and $c t f B$ genes. The plasmid pFC005 contained $a d h$ and $a d c$ genes and pFC006 contained adh, ctfA and $\operatorname{ctf} B$ genes (Table 1).

\section{Expression of isopropanol pathway genes in E. coli}

To assess their ability to promote isopropanol production, the constructs pFC002, pFC005, pFC006, pFC007 and pMTL500E were co-transformed with pTHL plasmid into E. coli BW25113. The pTHL plasmid contained the thiolase gene (thl) from $C$. acetobutylicum ATCC 824 (Stim-Herndon et al. 1995) to allow sufficient formation of acetoacetyl-CoA by E. coli. Productions of solvents by $E$. coli transformants are shown in Figure 1. All transformants produced ethanol, but only the transformants which, in addition to thiolase and $a d h$ genes, expressed $c t f A$ and $c t f B$ genes, i.e. transformants harbouring pFC006 (thl $\left.l_{p_{-}}[a d h ; c t f A ; c t f B]\right)$ or $\mathrm{pFC007}$ $\left(t h l_{p \_}[a d h ; a d c ; c t f A ; c t f B]\right)$ plasmids, produced isopropanol (3-8 $\mathrm{mM})$. The $E$. coli transformants harbouring pTHL and pFC005 (thl $\left.p_{-}[a d h ; a d c]\right)$ plasmids or harbouring pTHL and pMTL500E (control) plasmids did not produce isopropanol.

\section{Effect of expression of the adh gene on the product pool of C. acetobutylicum}

Plasmids pMTL500E, pFC002, pFC005, pFC006 and pFC007 were independently electroporated into C. acetobutylicum. The fermentation performance of the different $C$. acetobutylicum transformant strains was studied and compared with those of the wildtype strains (WT) in batch cultures performed in bioreactors with a 1 L-working volume. Cultures were performed with or without $\mathrm{pH}$ regulation. When $\mathrm{pH}$ regulated, the system was setup in such a way that once the $\mathrm{pH}$ had dropped to 5.0 it was kept at that level by the addition of $\mathrm{KOH}$. Table 3 shows final fermentation performances of $C$. acetobutylicum transformants with $\mathrm{pH}$ regulation at 5.0.

Expression of adh by strains ATCC 824(pFC002), ATCC 824(pFC005), ATCC 824(pFC006) and ATCC 824 ( $\mathrm{pFC007)} \mathrm{resulted} \mathrm{in} \mathrm{the} \mathrm{reduction} \mathrm{to} \mathrm{isopropanol} \mathrm{of}$ about $95 \%$ of the acetone natively produced. In contrast to ATCC 824 WT or ATCC 824(pMTL500E) that produced between 0.5 and $1.1 \mathrm{~g} / \mathrm{L}$ acetoin (3-hydroxy-2-

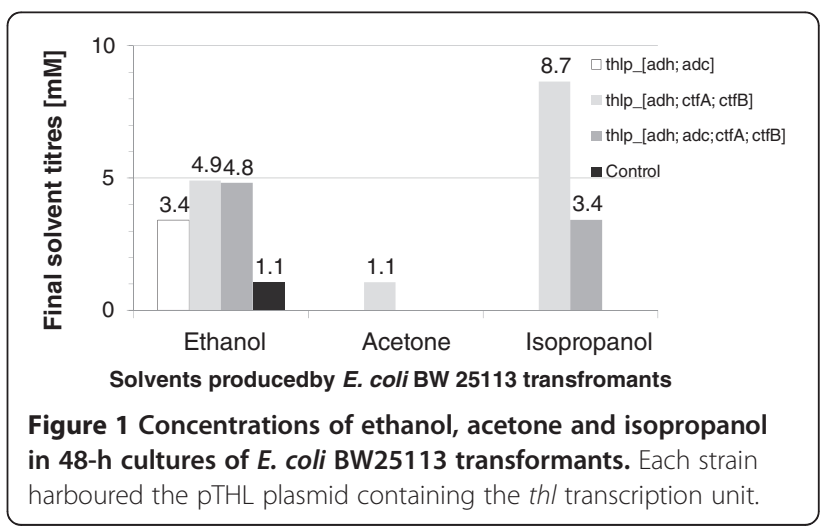


Table 3 Performance of C. acetobutylicum ATCC 824 and its transformants in 45-h cultures performed with pH regulation at $\mathbf{5 . 0}$

\begin{tabular}{|c|c|c|c|c|c|c|c|}
\hline \multirow[t]{2}{*}{ Performances } & \multirow{2}{*}{$\begin{array}{c}C . \\
\text { beijerinckii2 } \\
\text { NRRL B593 }^{2}\end{array}$} & \multicolumn{6}{|c|}{ C. acetobutylicum ATCC 824} \\
\hline & & WT & (pMTL500E) & (pFC002) & (pFC005) & (pFC006) & (pFC007) \\
\hline Glucose consumed $[\mathrm{g} / \mathrm{L}]$ & $36.8(1.7)$ & $62.3(0.4)$ & $62.5(2.4)$ & $53.0(7.9)$ & $56.3(2.2)$ & $68.0(4.3)$ & $68.1(0.1)$ \\
\hline Acetic acid ${ }^{1}[g / L]$ & $-1.7(0.0)$ & $0.3(0.4)$ & $0.4(1.8)$ & $1.8(1.2)$ & $1.2(0.2)$ & $1.0(1.0)$ & $0.0(0.1)$ \\
\hline Butyric acid $[g / L]$ & $0.3(0.1)$ & $1.7(0.4)$ & $1.3(0.4)$ & $2.6(0.8)$ & $2.5(0.5)$ & $2.1(1.6)$ & $1.4(0.0)$ \\
\hline Acetoin $[\mathrm{g} / \mathrm{L}]$ & $0.0(0.0)$ & $1.1(0.1)$ & $0.8(0.1)$ & $0.0(0.0)$ & $0.1(0.0)$ & $0.0(0.0)$ & $0.1(0.0)$ \\
\hline 2,3-Butanediol (D or $\mathrm{L}$ ) [g/L] & $0.0(0.0)$ & $0.0(0.0)$ & $0.0(0.0)$ & $0.5(0.3)$ & $0.5(0.1)$ & $0.6(0.3)$ & $0.6(0.1)$ \\
\hline Ethanol $[\mathrm{g} / \mathrm{L}]$ & $0.1(0.0)$ & $1.1(0.2)$ & $0.8(0.2)$ & $1.1(0.3)$ & $0.7(0.0)$ & $1.0(0.3)$ & $0.8(0.7)$ \\
\hline Acetone $[\mathrm{g} / \mathrm{L}]$ & $0.2(0.0)$ & $5.7(0.0)$ & $5.4(1.0)$ & $0.1(0.1)$ & $0.1(0.0)$ & $0.3(0.2)$ & $0.9(0.9)$ \\
\hline Isopropanol [g/L] & $4.5(0.3)$ & $0.1(0.1)$ & $0.1(0.1)$ & $4.8(0.8)$ & $6.1(0.1)$ & $7.2(0.5)$ & $7.3(0.3)$ \\
\hline Butanol $[\mathrm{g} / \mathrm{L}]$ & $8.4(1.9)$ & $10.0(1.5)$ & $10.1(1.5)$ & $9.1(1.6)$ & $9.7(0.3)$ & $11.3(0.8)$ & $11.3(0.5)$ \\
\hline Final solvents $[g / L]$ & $13.2(2.3)$ & $16.9(1.3)$ & $16.4(2.7)$ & $15.1(2.0)$ & $16.7(0.4)$ & $19.8(1.5)$ & $20.4(0.1)$ \\
\hline Final solvent yield $\left[g_{\mathrm{A} / \mathrm{IBE}} / \mathbf{g}_{\mathrm{glc} .}\right]$ & $0.36(0.1)$ & $0.27(0.02)$ & $0.29(0.07)$ & $0.29(0.04)$ & $0.30(0.01)$ & $0.29(0.02)$ & $0.30(0.00)$ \\
\hline Productivity after $30 \mathrm{~h}[\mathrm{~g} / \mathrm{L} \mathrm{h}]$ & $0.37(0.03)$ & $0.38(0.05)$ & $0.34(0.11)$ & $0.26(0.13)$ & $0.31(0.02)$ & $0.54(0.11)$ & $0.67(0.02)$ \\
\hline Carbone recovery [\%] & $98 \%$ & $90 \%$ & $86 \%$ & $101 \%$ & $102 \%$ & $96 \%$ & $95 \%$ \\
\hline
\end{tabular}

Cultures were performed in $1 \mathrm{~L}$-working volume of CM1 containing $3.0 \mathrm{~g} / \mathrm{L}$ ammonium acetate and $90 \mathrm{~g} / \mathrm{L}$ glucose.

All data are given as the mean of two or three fermentations the standard error to the mean is indicated in brackets.

1 a negative value (-) indicates that initial acetic acid from culture medium was partially consumed.

${ }^{2}$ Fermentations were carried out at $\mathrm{pH} 5.0$ but the $\mathrm{pH}$ set-point was not reached.

butanone) (Jones and Woods 1986; Xiao and Xu 2007), very low concentrations of acetoin were detected in cultures of transformants expressing the adh gene. However, D and/or L 2,3-butanediol (2,3-BD) accumulated at $0.5-0.6 \mathrm{~g} / \mathrm{L}$ when the $\mathrm{pH}$ was regulated at 5.0 and at $0.6-$ $1.2 \mathrm{~g} / \mathrm{L}$ when the $\mathrm{pH}$ was not regulated. No meso-2,3-BD was identified. Production of 2,3-BD was concomitant with production of IBE. It is worth noting that 2,3-BD was not detected in cultures of $C$. beijerinckii NRRL B593, probably because the organism does not produce acetoin. The enzymatic reduction of acetone and acetoin by cell-free extracts of ATCC 824(pMTL500E), ATCC 824(pFC002), ATCC 824(pFC007) and NRRL B593 WT was tested in vitro (Table 4). The cell-free extracts of ATCC 824(pFC002), ATCC 824(pFC007) and NRRL B593 WT displayed significantly higher reduction activities towards acetone and acetoin than those of ATCC 824(pMTL500E) used as control (Table 4).
Early isopropanol production in static flask culture

As the constitutive promoter of the thl gene was used to control gene expression (Tummala et al. 1999), the isopropanol production by ATCC 824(pFC007) was expected to start concomitantly with the production of butyric acid. Product excretion in the first hours of fermentation was studied in static flask fermentations. Butyric acid was detected prior to any solvent in all cultures of ATCC 824 transformants. The transformants expressing $\operatorname{ctf} A$ and $\operatorname{ctf} B$ genes i.e. harbouring pFC006 and pFC007 excreted isopropanol earlier than the wild type strain or other transformants (data not shown) and prior to any other solvent.

\section{Kinetics of IBE production by C. acetobutylicum transformants}

The fermentation kinetics of ATCC 824 transformants were first investigated using a $\mathrm{pH}$ set-point of 5.0. The

Table 4 Reduction activities of acetone and acetoin measured in cell-free extracts of C. beijerinckii NRRL B593 and C. acetobutylicum ATCC 824 transformants harbouring pMTL500E, pFC002 and pFC007

\begin{tabular}{|c|c|c|c|c|}
\hline \multicolumn{2}{|c|}{ Strain } & \multicolumn{3}{|c|}{ Specific activity $\left[\mu \mathrm{mol} / \mathrm{min} \mathrm{mg}_{\text {protein }}\right]$} \\
\hline & & acetone & acetoin & Control* \\
\hline C. beijerinckii & NRRL B593 & 0.063 & 0.069 & 0.015 \\
\hline C. acetobutylicum & ATCC 824(pMTL500E) & 0.002 & 0.007 & 0.003 \\
\hline C. acetobutylicum & ATCC 824(pFC002) & 0.152 & 0.069 & 0.009 \\
\hline C. acetobutylicum & ATCC 824(pFC007) & 0.076 & 0.118 & 0.018 \\
\hline
\end{tabular}

Cell biomass used for CFE was taken from $20 \mathrm{~h}$ cultures.

Data are given as the mean of two replicates.

${ }^{*}$ In control assays, substrate was replaced by HEPES buffer. 
fermentation profile and performances of the control strain ATCC 824(pMTL500E) were similar to those of C. acetobutylicum ATCC $824 \mathrm{WT}$ in the first $45 \mathrm{~h}$ of fermentation (Table 3). The expression of only the adh gene in ATCC 824(pFC002) resulted in lower solvent production (15.1 g/L IBE of which $4.8 \mathrm{~g} / \mathrm{L}$ isopropanol) than ATCC 824(pMTL500E) without the adh gene. Moreover, the productivity of ATCC 824(pFC002) at $30 \mathrm{~h}$ was $25 \%$ lower than that of ATCC 824(pMTL500E). In comparison to ATCC 824(pFC002), the wild-type IBE-producer C. beijerinckii NRRL B593 excreted less IBE (13.2 g/L of which $4.5 \mathrm{~g} / \mathrm{L}$ isopropanol), but reassimilated more efficiently the acids previously excreted. Thus NRRL B593 displayed higher solvent yield (0.36 $\mathrm{g}_{\text {IBE }} / \mathrm{g}_{\text {glc }}$ for NRRL B593 vs 0.29-0.30 $\mathrm{g}_{\mathrm{IBE}} / \mathrm{g}_{\text {glc }}$ for ATCC 824(pFC002)).

ATCC 824(pFC007) surpassed ATCC 824(pFC002) in the production of IBE, indicating that the overall metabolic activity was stimulated by the expression of pFC007 genes. ATCC 824(pFC007) produced more solvents $(20.4 \mathrm{~g} / \mathrm{L}$ IBE of which $7.3 \mathrm{~g} / \mathrm{L})$ and less acids than ATCC 824(pFC002) (15.1 g/L IBE of which $4.8 \mathrm{~g} / \mathrm{L}$ isopropanol). In addition, the fermentation period was shorter and stopped about 10-15 hours earlier than for ATCC 824(pFC002) (Figure 2). Consequently, the solvent productivity after $30 \mathrm{~h}$ by ATCC 824(pFC007) (0.67 g/L h) was 2.6 times higher than that of ATCC 824(pFC002).

Cultures of ATCC 824(pFC005) and ATCC 824 (pFC006) were performed to evaluate the contribution of each gene to the improvement of the ATCC 824(pFC007) phenotype (Table 3). Both strains produced more IBE than ATCC 824(pFC002). The combined overexpression of the $c t f A$ and $c t f B$ genes along with expression of $a d h$ conferred to ATCC 824(pFC006) a fermentation profile similar to that of ATCC 824(pFC007) (Table 3). The final concentration of acids in the ATCC 824(pFC006) culture was slightly lower than that of ATCC 824(pFC002). As with ATCC 824(pFC007), fermentations with ATCC 824(pFC006) stopped 10-15 hours earlier than with the other transformants (Figure 2). The resulting solvent productivity after $30 \mathrm{~h}(0.62 \mathrm{~g} / \mathrm{L} \mathrm{h})$ was 2.0 times higher than ATCC 824(pFC002). In ATCC 824 (pFC005), the overexpression of adc along with expression of $a d h$ gene had a more pronounced effect on the production of isopropanol $(+27 \%)$ than on the production of butanol $(+7 \%)$ when compared with ATCC 824(pFC002). The fermentation performances of ATCC 824(pFC005) were lower than those of ATCC 824(pFC006) or ATCC 824(pFC007) and no shortening of the fermentation period was observed. Besides, ATCC 824(pFC005), ATCC 824 (pFC006) and ATCC 824(pFC007) exhibited the same solvent yield than ATCC 824(pFC002), ATCC 824(pMTL500E) and the WT.

\section{Effect of pH control}

In order to assess the effect of the culture mode, another set of fermentations was performed without $\mathrm{pH}$ control (Table 5). For every strain tested, the minimum $\mathrm{pH}$ value reached was 4.7-4.8 (data not shown). The glucose consumptions were roughly similar to those without $\mathrm{pH}$ regulation. A better reassimilation of acetic and butyric acids was observed leading to better solvent titres, yields and productivities. The excretion profiles of metabolites for each strain were similar to the corresponding ones with $\mathrm{pH}$ regulation at 5.0. The highest solvent productions were obtained with ATCC 824(pFC007) that produced $24.4 \mathrm{~g} / \mathrm{L}$ IBE (of which $8.8 \mathrm{~g} / \mathrm{L}$ was isopropanol) and ATCC 824(pFC006) that produced $24.0 \mathrm{~g} / \mathrm{L} \mathrm{IBE} \mathrm{(of}$ which $8.0 \mathrm{~g} / \mathrm{L}$ was isopropanol). Lack of sporulation and extensive cell lysis were observed in cultures of ATCC 824(pFC006) or ATCC 824(pFC007) performed without $\mathrm{pH}$ control, highlighting the strong inhibitory effect of solvents in the early phase of cellular growth.

\section{Discussion}

In the latest developments related to the $\mathrm{ABE}$ fermentation process, acetone was considered to be indesirable co-product, whereas butanol is the main product of interest. Over the past few decades, various strategies have been developed to decrease the production of acetone and increase the production of butanol (Nair et al. 1994; Nair and Papoutsakis 1994; Harris et al. 2000; Sillers et al. 2008; Jiang et al. 2009; Sillers et al. 2009; Han et al. 2011). The intracellular conversion of acetone into isopropanol was an attractive alternative to avoid acetone excretion and produce a valuable alcohol. The $C$. beijerinckii NRRL B593 strain reduced acetone naturally thanks to a secondary-alcohol dehydrogenase (s-Adh) but the final titres of solvents by the NRRL B593 (George et al. 1983; Survase et al. 2011) were lower than those of the best ABE producers (Monot et al. 1982; Qureshi and Blaschek 1999).

In this study, we have constructed four plasmids harbouring the adh gene from C. beijerinckii NRRL B593 and the genes from $C$. acetobutylicum ATCC 824 that are part of the metabolic pathway from acetoacetyl-CoA to acetone. The cloned genes were successfully expressed in both E. coli BW25113 and C. acetobutylicum ATCC 824. In $E$. coli, the expression of $c t f A$ and $c t f B$ along with $a d h$ and $t h l$ genes allowed for the production of isopropanol. The lack of the $a d c$ gene did not prevent the decarboxylation of acetoacetate by $E$. coli harbouring pFC006, probably because of the instability of the molecule in acidic conditions (Hay and Bond 1967). The final concentration of isopropanol in cultures of $E$. coli strains 
a

(pH 5.0)

1

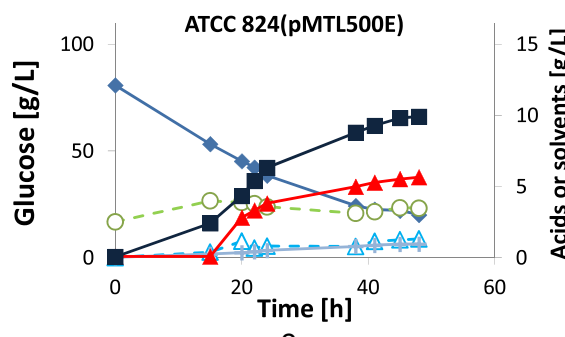

2

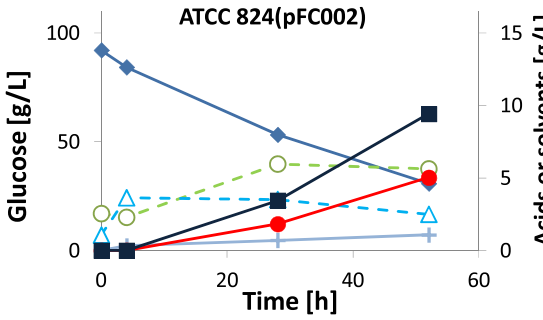

3

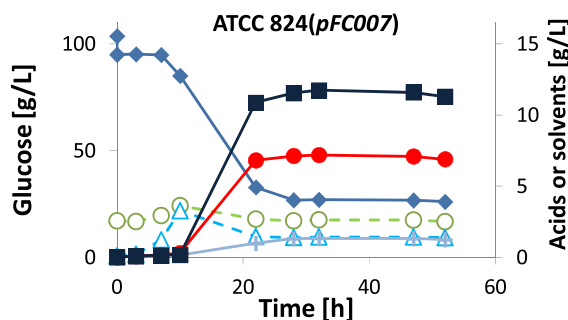

b

(without pH control)

1

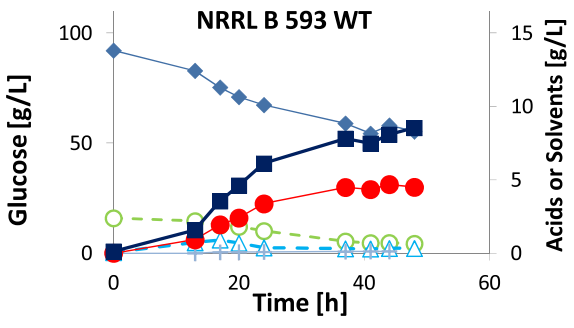

2

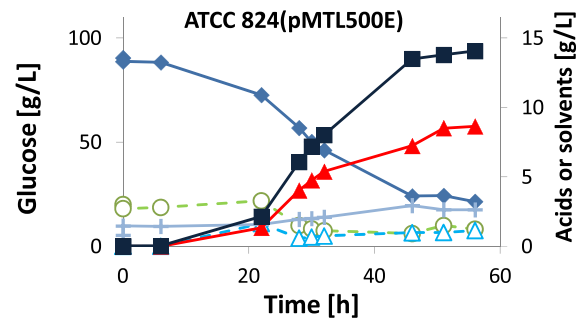

3

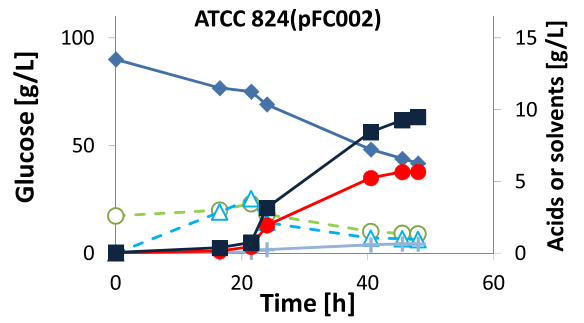

4

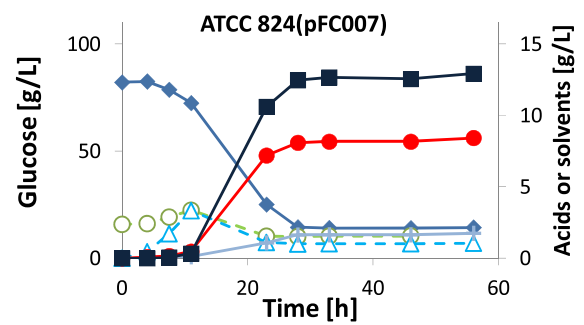

Figure 2 Fermentation kinetics of C. beijerinckii NRRL B593 WT and C. acetobutylicum ATCC 824 WT and its transformants. Column a: $\mathrm{pH}$ regulated to 5.0; column b: pH not regulated. Glucose (Closed diamonds), acetic acid (open circles), butyric acid (open triangles), ethanol (crosses), isopropanol (closed circles), acetone (closed triangles) and butanol (closed squares).

expressing $c t f A$ and $c t f B$ genes (pTHL and pFC006 or pTHL and pFC007) was lower than those previously reported by other groups (Hanai et al. 2007; Atsumi and Liao 2008; Jojima et al. 2008; Yoshino et al. 2008). In our study, E. coli cultures were not optimised, but carried out with the purpose of checking the validity of each construct.

The plasmids were electroporated in C. acetobutylicum ATCC 824. The expression of $a d h$ gene allowed transformants to reduce natively produced acetoin and acetone to 2,3-BD and isopropanol, respectively. Either the D or L forms of 2,3-BD or a combination of both but no meso2,3-BD was produced. The achiral HPLC used in the present study did not differentiate between the $\mathrm{D}$ and $\mathrm{L}$ enantiomers. Since the activity of s-Adh on acetoin had never been described, this result extends the range of substrates known for this enzyme (Ismaiel et al. 1993). Recently, the production of 2,3-BD by $C$. acetobutylicum transformants expressing an acetoin reductase $(a c r)$ from C. beijerinckii NCIMB 8052 was reported (Siemerink et al. 2011). The resulting strains also produced 2,3-BD but did not produced isopropanol. For future applications, the 
Table 5 Performance of C. acetobutylicum ATCC 824 and its transformants in 45-h cultures performed without pH regulation

\begin{tabular}{|c|c|c|c|c|c|c|}
\hline \multirow[t]{2}{*}{ Performances } & \multicolumn{6}{|c|}{ C. acetobutylicum ATCC 824} \\
\hline & WT & (pMTL500E) & $(\mathrm{pFC002)}$ & (pFC005) & (pFC006) & $(\mathrm{pFC007)}$ \\
\hline Glucose consumed [g/L] & $65.0(1.0)$ & $61.6(4.2)$ & $50.1(5.6)$ & $59.3(2.5)$ & $67.9(7.0))$ & $70.0(1.9)$ \\
\hline Acetic acid ${ }^{*}[g / L]$ & $-1.6(0.1)$ & $-1.8(0.0)$ & $-1.3(0.1)$ & $-2.0(0.1)$ & $-1.2(0.2)$ & $-1.4(0.8)$ \\
\hline Butyric acid [g/L] & $1.1(0.1)$ & $1.1(0.1)$ & $1.0(0.0)$ & $1.1(0.1)$ & $0.6(0.3)$ & $0.8(0.3)$ \\
\hline Acetoin $[\mathrm{g} / \mathrm{L}]$ & $1.1(0.1)$ & $0.8(0.0)$ & $0.0(0.0)$ & $(0.0(0.0)$ & $0.0(0.0)$ & $0.1(0.1)$ \\
\hline 2,3-Butanediol (D or L) [g/L] & $0.0(0.0)$ & $0.0(0.0)$ & $0.6(0.0)$ & $0.7(0.2)$ & $0.8(0.2)$ & $1.2(0.6)$ \\
\hline Ethanol $[\mathrm{g} / \mathrm{L}]$ & $0.9(0.0)$ & $1.2(0.4)$ & $1.6(0.2)$ & $0.9(0.1)$ & $3.1(1.7)$ & $1.5(0.6)$ \\
\hline Acetone $[\mathrm{g} / \mathrm{L}]$ & $7.6(0.1)$ & $7.2(0.0)$ & $0.7(0.1)$ & $0.0(0.0)$ & $0.3(0.1)$ & $0.1(0.1)$ \\
\hline Isopropanol [g/L] & $0.1(0.0)$ & $0.1(0.0)$ & $6.0(0.5)$ & $8.2(0.1)$ & $8.0(0.4)$ & $8.8(0.7)$ \\
\hline Butanol $[\mathrm{g} / \mathrm{L}]$ & $11.6(0.2)$ & $12.6(1.3)$ & $9.5(0.3)$ & $12.1(0.2)$ & $13.4(1.5)$ & $13.7(1.6)$ \\
\hline Final solvents $[\mathrm{g} / \mathrm{L}]$ & $20.2(0.3)$ & $21.1(1.6)$ & $16.2(0.9)$ & $21.3(0.2)$ & $24.0(2.5)$ & $24.4(2.8)$ \\
\hline Final solvent yield $\left[\mathbf{g}_{\mathrm{A} / \mathrm{BEE}} / \mathbf{g}_{\mathrm{glc} .}\right]$ & $0.31(0.01)$ & $0.34(0.00)$ & $0.33(0.02)$ & $0.36(0.01)$ & $0.35(0.00)$ & $0.35(0.04)$ \\
\hline Productivity after $30 \mathrm{~h}[\mathrm{~g} / \mathrm{L} \mathrm{h}]$ & $0.38(0.00)$ & $0.42(0.01)$ & $0.28(0.02)$ & $0.30(0.00)$ & $0.72(0.04)$ & $0.80(0.11)$ \\
\hline Carbone recovery [\%] & $89 \%$ & $94 \%$ & $102 \%$ & $100 \%$ & $105 \%$ & $101 \%$ \\
\hline
\end{tabular}

Cultures were performed in $1 \mathrm{~L}$-working volume of CM1 containing $3.0 \mathrm{~g} / \mathrm{L}$ ammonium acetate and $90 \mathrm{~g} / \mathrm{L}$ glucose.

All data are given as the mean of two or three fermentations the standard error to the mean is indicated in brackets.

* a negative value (-) indicates that initial acetic acid from culture medium was partially consumed.

production of 2,3-BD by ATCC 824 transformants is still very far from that of Klebsiella pneumoniae (up to $150 \mathrm{~g} / \mathrm{L}$ of 2,3-BD) (Ma et al. 2009).

Each transformant of ATCC 824 was characterised in a batch culture either with $\mathrm{pH}$ regulation at 5.0 or without $\mathrm{pH}$ regulation. All transformants of ATCC 824 and the wild type displayed higher solvent production levels when grown without $\mathrm{pH}$-regulation. The solvent yield based on glucose consumption did not depend on the genetic modifications, but rather on the culture conditions ( $\mathrm{pH}$ control or not). Acid assimilation was improved in the cultures without $\mathrm{pH}$ regulation, as also suggested by the increase of the $\mathrm{C} 3$ compound (acetone or isopropanol) productions. When the $\mathrm{pH}$ was not regulated, the $\mathrm{pH}$ value of the culture dropped below 5.0, increasing the concentrations of the protonated form of the acids. This has been associated with the onset of solventogenesis (Monot et al. 1984; Hüsemann and Papoutsakis 1988). Therefore, the high level of protonated acid forms in $\mathrm{pH}$ not-regulated cultures of ATCC 824 transformants might trigger solventogenesis at a lower concentration of total acids (protonated plus ionized) and drive more the carbon flux towards butanol or ethanol formation.

The expression of only the $a d h$ gene lowered total solvent production by ATCC $824(\mathrm{pFC002})$ compared to the wild type and the transformant harbouring the empty vector (pMTL500E). The lower solvent excretion by ATCC 824(pFC002) could be explained by the higher toxicity of isopropanol compared to acetone, as suggested by the octane/water partition coefficients $\left(\log \mathrm{K}_{\mathrm{ow}}\right)$ values i.e. 0.05 for isopropanol and -0.25 for acetone (Yaws and Sachin 1999). The $\log K_{\text {ow }}$ was reported to be a good estimation for solvent toxicity (Vermue et al. 1993; Heipieper et al. 1994), high $\log \mathrm{K}_{\mathrm{ow}}$ compounds are generally more toxic than compounds with lower value. It has to be noted that the final IBE concentration of ATCC 824(pFC002) cultures $(16 \mathrm{~g} / \mathrm{L})$ was still higher than that of NRRL B593 cultures $(13 \mathrm{~g} / \mathrm{L})$ suggesting that the solvent sensitivity is a strain-dependent characteristic.

Under all culture conditions tested, the overexpression of all genes encoding enzymes of the acetone route ( $c t f A$, ctfB and $a d c$ ), along with expression of $a d h$ gene, conferred to ATCC 824(pFC007) high solvent production rate and high final solvent titres. The use of thl promoter to control the expression of $\operatorname{ctf} A$ and $\operatorname{ctf} B$ genes initiated excretion of isopropanol before those of other solvents. Recently, Lee et al. (2012) have developed a transformant comparable with ATCC 824(pFC007) in which expression of isopropanol pathway genes were controlled by two adc promoters. In batch culture with $\mathrm{pH}$ regulation at 5.0, the maximal end-concentration of IBE was only $17.1 \mathrm{~g} / \mathrm{L}$ of which $6.1 \mathrm{~g} / \mathrm{L}$ was isopropanol. The difference in solvent productions observed in the two studies might result from the culture mode applied. Fed-batch with gas stripping was used and was found to improve IBE production by $35.6 \mathrm{~g} / \mathrm{L}$ (Lee et al. 2012) but this type of process has never been scaled up.

The role of each gene involved in the pathway from acetoacetyl-CoA to acetone in the enhancement of ATCC 824(pFC007) fermentation performances was clarified by expressing two derivative plasmids. The 
overexpression of the $c t f A$ and $c t f B$ genes increased both the speed and the extent of acid assimilation while the overexpression of the $a d c$ gene had a little effect (Table 3).

This result indicates that decarboxylation of acetoacetate is not the real bottleneck. In a previous study on $\mathrm{ABE}$ production by ATCC 824, the overexpression of $c t f A, c t f B$ and $a d c$ genes controlled by the $a d c$ promoter was studied at pH 5.5 (Mermelstein et al. 1993). As with our results, the combined overexpression of $\operatorname{ctf} A, \operatorname{ctf} B$ and $a d c$ increased the solvent production by transformants, whereas expression of $a d c$ gene alone had little effect. Unlike our results, the combined expression of $c t f A$ and $c t f B$ genes without $a d c$ was found to have a limited effect. Therefore, the impact of $\operatorname{ctf} A$ and $\operatorname{ctfB}$ overexpression observed in our study might have been supported by the chemically acid-calalysed decarboxylation of acetoacetate (Hay and Bond 1967).

\section{Conclusion}

The expression of $c t f A$ and $c t f B$ genes along with the $a d h$ gene in $C$. acetobutylicum appears to be a promising way for constructing efficient isopropanol/ethanol producers. The transformants in the present study produce the highest total IBE concentration reported for clostridial batch cultures without online IBE removal $(24.4 \mathrm{~g} / \mathrm{L})$. As the IBE alcohol mix is considered to be a valuable fuel additive, the transformants obtained represent a step forward towards the development of an industrial IBE process for the production of biofuels.

\section{Competing interest}

The authors declare that they have no competing interests.

\begin{abstract}
Acknowledgements
This work was supported by the program EnerBio of the French Tuck foundation. The authors wish to thank Ms Hetty van der Wal, Ms Miriam Budde for their assistance in fermentation work and Rachel Licht for her critical reading of the manuscript and improvement of the English.
\end{abstract}

\begin{abstract}
Author details
${ }^{1}$ Food and Biobased Research, Wageningen University and Research Centre, Bornse Weilanden 9, 6708, WG Wageningen, Netherlands. ${ }^{2}$ IFP Energie Nouvelles, Biotechnology Department, 1-4 Avenue Bois-Préau, 92852, Rueil-Malmaison, France. ${ }^{3}$ Current address: Clostridia Research Group, BBSRC Sustainable Bioenergy Centre, School of Molecular Medical Sciences, Centre for Biomolecular Sciences, University of Nottingham, University Park, Nottingham NG7 2RD, UK.
\end{abstract}

Received: 2 July 2012 Accepted: 6 July 2012 Published: 21 August 2012

\section{References}

Alsaker KV, Papoutsakis ET (2005) Transcriptional Program of Early Sporulation and Stationary-Phase Events in Clostridium acetobutylicum. J Bacteriol 187:7103-7118

Atsumi S, Liao JC (2008) Metabolic engineering for advanced biofuels production from Escherichia coli. Curr Opin Biotechnol 19:414-419

Bermejo LL, Welker NE, Papoutsakis ET (1998) Expression of Clostridium acetobutylicum ATCC 824 genes in Escherichia coli for acetone production and acetate detoxification. Appl Environ Microbiol 64:1079-1085
Bertani G (2004) Lysogeny at mid-twentieth century: P1, P2, and other experimental systems. J Bacteriol 186:595-600

Chen JS (1995) Alcohol-dehydrogenase: multiplicity and relatedness in the solvent-producing Clostridia. FEMS Microbiol Rev 17:263-273

Chen JS, Hiu SF (1986) Acetone-butanol-isopropanol production by Clostridium beijerinckii (synonym, Clostridium butylicum). Biotechnol Lett 8:371-376

Dürre P (2007) Biobutanol: An attractive biofuel. Biotechnol J 2:1525-1534

Dürre P (2008) Fermentative butanol production, Bulk chemical and biofuel. Ann N Y Acad Sci 1125:353-362

George HA, Johnson JL, Moore WEC, Holdeman LV, Chen JS (1983) Acetone, isopropanol and butanol production by Clostridium beijerinckii (syn. Clostridium butylicum) and Clostridium aurantibutyricum. Appl Environ Microbiol 45:1160-1163

Girbal L, Soucaille P (1998) Regulation of solvent production in Clostridium acetobutylicum. Trends Biotechnol 16:11-16

Goihberg E, Peretz M, Tel-Or S, Dym O, Shimon L, Frolow F, Burstein Y (2010) Biochemical and structural properties of chimeras constructed by exchange of cofactor-binding domains in alcohol dehydrogenases from thermophilic and mesophilic microorganisms. Biochem 49:1943-1953

Gosselink RJA, van Dam JEG, Zomers FHA (1995) Combined HPLC analysis of organic acids and furans formed during organosolv pulping of fiber hemp. J Wood Chem Technol 15:1-25

Green E (2011) Fermentative production of butanol: the industrial perspective. Curr Opin Biotechnol 22:337-343

Groot WJ, Luyben KCAM (1986) In situ product recovery by adsorption in the butanol isopropanol batch fermentation. Appl Microbiol Biotechnol 25:29-31

Han B, Gopalan V, Ezeji TC (2011) Acetone production in solventogenic Clostridium species: new insights from non-enzymatic decarboxylation of acetoacetate. Appl Microbiol Biotechnol 91:565-576

Hanai T, Atsumi S, Liao JC (2007) Engineered synthetic pathway for isopropanol production in Escherichia coli. Appl Environ Microbiol 73:7814-7818

Harris LM, Desai RP, Welker NE, Papoutsakis ET (2000) Characterization of recombinant strains of the Clostridium acetobutylicum butyrate kinase inactivation mutant: Need for new phenomenological models for solventogenesis and butanol inhibition? Biotechnol Bioeng 67:1-11

Hartmanis MGN, Gatenbeck S (1984) Intermediary metabolism in Clostridium acetobutylicum: levels of enzymes involved in the formation of acetate and butyrate. Appl Environ Microbiol 47:1277-1283

Hay RW, Bond MA (1967) Kinetics of decarboxylation of acetoacetic acid. Australian J Chem 20:1823-1828

Heap JT, Pennington OJ, Cartman ST, Carter GP, Minton NP (2007) The ClosTron: A universal gene knock-out system for the genus Clostridium. J Microbiol Meth 70:452-464

Heipieper HJ, Weber FJ, Sikkema J, Keweloh H, Debont JAM (1994) Mechanisms of resistance of whole cells to toxic organic-solvents. Trends Biotechnol 12:409-415

Huang TJ, Sorensen CM, Varghese P (1990) Process for the production of ethers. USA, 4,906,787

Hüsemann MHW, Papoutsakis ET (1988) Solventogenesis in Clostridium acetobutylicum fermentations related to carboxylic-acid and proton concentrations. Biotechnol Bioeng 32:843-852

Ismaiel AA, Zhu CX, Colby GD, Chen JS (1993) Purification and characterization of a primary-secondary alcohol dehydrogenase from two strains of Clostridium beijerinckii. J Bacteriol 175:5097-5105

Jiang Y, Xu CM, Dong F, Yang YL, Jiang WH, Yang S (2009) Disruption of the acetoacetate decarboxylase gene in solvent-producing Clostridium acetobutylicum increases the butanol ratio. Metab Eng 11:284-291

Jojima T, Inui M, Yukawa H (2008) Production of isopropanol by metabolically engineered Escherichia coli. Appl Microbiol Biotechnol 77:1219-1224

Jones DT, Woods DR (1986) Acetone-butanol fermentation revisited. Microbiol Rev 50:484-524

Korkhin Y, Kalb AJ, Peretz M, Bogin O, Burstein Y, Frolow F (1998) NADPdependent bacterial alcohol dehydrogenases: Crystal structure, cofactorbinding and cofactor specificity of the ADHs of Clostridium beijerinckii and Thermoanaerobacter brockii. J Mol Biol 278:967-981

Kuit W, Lopez Contreras AM, Eggink G (2012) Disruption of the acetate kinase (ack) gene of Clostridium acetobutylicum results in delayed acetate production. Appl Biochem Biotechnol 9:729-741

Lee J, Yu-Sin J, Joon Choi S, Ae Im J, Song H, Hee Cho J, Seung DY, Papoutsakis ET, Bennett GN, Lee SY (2012) Metabolic engineering of Clostridium 
acetobutylicum ATCC 824 for isopropanol-butanol-ethanol fermentation. Appl Environ Microbiol 78:1416-1423

Logsdon JE, Loke A (2000) Isopropyl alcohol. Kirk-Othmer Encyclopedia of Chemical Technology

López-Contreras AM, Kuit W, Siemerink MAJ, Kengen SWM, Springer J, Claassen PAM (2010) Production of longer-chain alcohols from lignocellulosic biomass: butanol, isopropanol and 2,3-butanediol. In: Waldron KW (ed) Bioalcohol production: Biochemical conversion of lignocellulosic biomass, vol 3, Woodhead Publishing Ltd. Abington, Cambridge (UK), pp 415-460

Ma C, Ailong W, Qin J, Li L, Ai X, Jiang T, Tang H, Xu P (2009) Enhanced 2,3butanediol production by Klebsiella pneumoniae SDM. Appl Microbiol Biotechnol 82:49-57

Matsumura M, Takehara S, Kataoka H (1992) Continuous butanol/isopropanol fermentation in down-flow column reactor coupled with pervaporation using supported liquid membrane. Biotechnol Bioeng 39:148-156

Mermelstein LD, Papoutsakis ET (1993) Invivo methylation in Escherichia coli by the Bacillus subtilis phage Phi-3 T-I methyl transferase to protect plasmids from restriction upon transformation of Clostridium acetobutylicum ATCC 824. Appl Environ Microbiol 59:1077-1081

Mermelstein LD, Papoutsakis ET, Petersen DJ, Bennett GN (1993) Metabolic engineering of Clostridium acetobutylicum ATCC 824 for increased solvent production by enhancement of acetone formation enzyme activities using a synthetic acetone operon. Biotechnol Bioeng 42:1053-1060

Monot F, Martin JR, Petitdemange H, Gay R (1982) Acetone and butanol production by Clostridium acetobutylicum in a synthetic medium. Appl Environ Microbiol 44:1318-1324

Monot F, Engasser J-M, Petitdemange $\mathrm{H}$ (1984) Influence of $\mathrm{pH}$ and undissociated butyric acid on the production of acetone and butanol in batch cultures of Clostridium acetobutylicum. Appl Microbiol Biotechnol 19:422-426

Nair RV, Papoutsakis ET (1994) Expression of plasmid encoded AAD in Clostridium acetobutylicum M5 restores vigorous butanol production. J Bacteriol 176:5843-5846

Nair RV, Bennett GN, Papoutsakis ET (1994) Molecular characterisation of an aldehyde/alcohol dehydrogenase gene from Clostridium acetobutylicum ATCC 824. J Bacteriol 176:871-885

Oultram JD, Loughlin M, Swinfield TJ, Brehm JK, Thompson DE, Minton NP (1988) Introduction of plasmids into whole cells of Clostridium acetobutylicum by electroporation. FEMS Microbiol Lett 56:83-88

Peralta-Yahya PP, Keasling JD (2010) Advanced biofuel production in microbes. Biotechnol J 5:147-162

Qureshi N, Blaschek HP (1999) Production of acetone butanol ethanol (ABE) by a hyper-producing mutant strain of Clostridium beijerinckii BA101 and recovery by pervaporation. Biotechnol Prog 15:594-602

Rogers P, Chen J-S, Zidwick M (2006) Organic acid and solvent production. Part III; butanol, acetone, isopropanol;1,3- and 1,2-propanediol production; and 2,3-butanediol production. In: Dworkin M (ed) The prokaryotes A handbook on the biology of bacteria, vol 1, 3rd edn. Springer, New York, USA, pp 672-755

Roos JW, McLaughlin JK, Papoutsakis ET (1985) The effect of pH on nitrogen supply, cell lysis, and solvent production in fermentations of Clostridium acetobutylicum. Biotechnol Bioeng 27:681-694

Siemerink MAJ, Kuit W, Lopez Contreras AM, Eggink G, van der Oost J, Kengen SWM (2011) D-2,3-butanediol production due to heterologous expression of an acetoin reductase in Clostridium acetobutylicum. Appl Environ Microbiol 77:2582-2588

Sillers R, Chow A, Tracy B, Papoutsakis ET (2008) Metabolic engineering of the non-sporulating, non-solventogenic Clostridium acetobutylicum strain M5 to produce butanol without acetone demonstrate the robustness of the acidformation pathways and the importance of the electron balance. Metab Eng 10:321-332

Sillers R, Hinai AMA, Papoutsakis ET (2009) Aldehyde-Alcohol Dehydrogenase and/or Thiolase Overexpression Coupled With CoA Transferase Downregulation Lead to Higher Alcohol Titers and Selectivity in Clostridium acetobutylicum Fermentations. Biotechnol Bioeng 102:38-49

Stim-Herndon KP, Petersen DJ, Bennett GN (1995) Characterisation of an acetylCoA C-acetyl transferase (Thiolase) gene from Clostridium acetobutylicum ATCC 824. Gene 154:81-85

Survase SA, Jurgens G, Heiningen A, Granström T (2011) Continuous production of isopropanol and butanol using Clostidium beijerinckii DSMZ 6423. Appl Microbiol Biotechnol 91:1305-1313
Tummala SB, Welker NE, Papoutsakis ET (1999) Development and characterization of a gene expression reporter system for Clostridium acetobutylicum ATCC 824. Appl Environ Microbiol 65:3793-3799

Vermue M, Sikkema J, Verheul A, Bakker R, Tramper J (1993) Toxicity of homologous series of organic-solvents for the gram positive bacteria Arthrobacter and Nocardia sp and the gram negative bacteria Acinetobacter and Pseudomonas sp. Biotechnol Bioeng 42:747-758

Xiao ZJ, Xu P (2007) Acetoin metabolism in bacteria. Crit Rev Microbiol 33:127-140

Yan RT, Zhu CX, Golemboski C, Chen JS (1988) Expression of solvent-forming enzymes and onset of solvent production in batch cultures of Clostridium beijerinckii ("Clostridium butylicum"). Appl Environ Microbiol 54:642-648

Yaws CL, Sachin N (1999) Solubitlity in water and octanol-water partition coefficient. In: Hill MG (ed) Chemical properties handbook

Yoshino S, Kawabe T, Ishibashi Y (2008) Aerobic isopropanol fermentation by genetically engineered Escherichia coli. In: Clostridium 10; 28 September 2008. Wageningen, The Netherlands

doi:10.1186/2191-0855-2-45

Cite this article as: Collas et al: Simultaneous production of isopropanol, butanol, ethanol and 2,3-butanediol by Clostridium acetobutylicum ATCC 824 engineered strains. AMB Express 2012 2:45.

\section{Submit your manuscript to a SpringerOpen ${ }^{\mathcal{D}}$ journal and benefit from:}

- Convenient online submission

- Rigorous peer review

- Immediate publication on acceptance

- Open access: articles freely available online

High visibility within the field

- Retaining the copyright to your article

Submit your next manuscript at $\gg$ springeropen.com 